\title{
How to Expand Repurchase Intention? Intervention Impact of Customer Satisfaction
}

\author{
Sri Widiastuti ${ }^{1 *}$, and Rifda Nabila $^{1}$ \\ ${ }^{1}$ Faculty of Islamic Economics and Business, IAIN Salatiga, Indonesia
}

\begin{abstract}
This study aims to determine the effect of halal lifestyle, halal awareness, price on repurchase intention with consumer satisfaction as an intervening variable at the Kedu Susu shop in Temanggung, Central Java. Researchers used quantitative data with a population of all visitors to the Temanggung Kedu Susu shop and used a sample of 100 respondents using purposive random sampling technique. The method used by the researcher is by distributing questionnaires through an online method. The researcher conducted an analysis using validity test, reliability test, classical assumption test, statistical test, and path analysis to test the intervening variables. The results of this study indicate that the halal lifestyle variable has no significant positive effect, halal awareness has no effect while price has a significant positive effect on repurchase interest. Consumer satisfaction has a significant positive effect on repurchase intention. The results of the path analysis test showed that consumer satisfaction was not able to mediate the effect of halal lifestyle on repurchase intention, while consumer satisfaction was able to mediate the effect of halal awareness and price on repurchase interest.
\end{abstract}

\section{Introduction}

Currently, the global trend is towards the development of the Halal economy. In the past, halal or non-halal only concerns food, but now halal is also expanding its scope to various other sectors of life. The Institute for the Study of Food, Drugs and Cosmetics of the Indonesian Ulema Council (LPPOM MUI) in 2016 noted that countries in the world have begun to seize opportunities in the halal market with MUI certification and Indonesia occupies the top position with 1001 halal certifications (Ismailia, 2018).

In 2016, the Indonesia Halal Lifestyle Center held the Indonesia International Halal Lifestyle Expo \& Conference (IIHLEC). The event is expected to encourage the halal industry in Indonesia and become part of the global halal calendar. In the article Satu (2016), Nirwan mentions that there are ten (10) sectors that economically and business contribute greatly to the halal industry. One of them is the food industry sector. Currently, the food industry sector is one of the sectors that gets more attention which makes the food industry grow rapidly, so that in recent years business people have competed to create various hangout places such as small shops/cafes, coffee shops, and even restaurants. which not only serves

\footnotetext{
* Corresponding author: sriwidiastuti381@gmail.com
} 


\section{$A \overline{I E B}$ Annual International Conference \\ on Islamic Economics and Business, 2021}

various types of food and drinks, but also an aesthetic/beauty place that can be used for taking pictures/selfies.

In recent years, there have been many cafes or hangouts in Temanggung, both in the city and in the villages. One of them, in 2012 the emergence of a milk shop located in Kedu District, Temanggung Regency, Central Java. The shop serves a variety of food and drinks. A different place and atmosphere that can be considered unique which makes customers interested in visiting it because it appears in the midst of many business people who make coffee shops.

The spread of business in the culinary world makes businesspeople must always be up to date and be able to innovate in accordance with the latest trends. Business people will form strategies that can attract customers to be interested in buying again. According to Kotler in Sudarti \& Ulum (2019), repurchase interest is buying interest based on past purchase experiences, repurchase interest reflects a high level of satisfaction from consumers in consuming a product.

In line with the halal lifestyle trend, Muslims want the products in the form of food and beverages to be consumed to be guaranteed halal and pure. Halal awareness is a person's awareness of a Muslim knowledge about the halal concept, the halal process, and considers that consuming halal food is important for him (Nikmatul, 2020). While a rational consumer, of course, in addition to promoting his lifestyle and awareness of being halal, price will also be an important factor for a consumer to be interested in buying back a product.

When someone is interested in repurchasing a product, of course, they have previously received satisfaction from the product they bought. Satisfaction is a level of someone stating the results of a comparison of the performance of a product or service that has been received and which has been expected (C.S.S., 2018). This study aims to analyze the influence of halal lifestyle, halal awareness, and price on repurchase intention with consumer satisfaction as an intervening variable.

\section{Method}

This type of research uses quantitative research with primary data types where the data obtained through the distribution of questionnaires or questionnaires with google form. This research was conducted in August 2021 in Temanggung Regency. The sample of this study were all visitors to the Kedu Susu shop with a sample of 100 respondents using the Purposive Random Sampling technique. The variables used in this study consisted of independent variables (independent variables) namely halal lifestyle, halal awareness, price, and the dependent variable (dependent variable) namely repurchase interest and the intervening variable, namely consumer satisfaction. This study uses analytical techniques in the form of validity tests, reliability tests, classical assumption tests, statistical tests ( $\mathrm{t}$ test, $\mathrm{f}$ test, and $\mathrm{r} 2$ test) and uses path analysis to test intervening variables with SPSS 20 application analysis software.

The hypotheses in this study are:

H1 : Halal Lifestyle has a positive and significant effect on repurchase intention.

$\mathrm{H} 2$ : Halal awareness has a positive and significant effect on repurchase intention.

H3 : Price has a positive and significant effect on repurchase interest.

H4 : Halal Lifestyle has a positive and significant effect on consumer satisfaction

H5 : Halal awareness has a positive and significant effect on consumer satisfaction

H6 : Price has a positive and significant effect on consumer satisfaction

$\mathrm{H} 7$ : Consumer satisfaction has a positive and significant effect on repurchase intention.

H8 : Customer satisfaction is able to mediate the relationship between Halal Lifestyle and repurchase intention. 


\section{$\mathrm{AIC} \overline{I E B} \quad \begin{gathered}\text { Annual International Conference } \\ \text { on Islamic Economics and Business, } 2021\end{gathered}$}

H9 : Customer satisfaction is able to mediate the relationship between halal awareness and repurchase intention.

H10: Customer satisfaction is able to mediate the relationship between price and repurchase intention.

\section{Result and Discussion}

\subsection{Validity Test}

Table 1. Validity Test Results

\begin{tabular}{|c|c|c|c|c|}
\hline Variable & Item Question & $r$ count & $\mathrm{r}$ table & Description \\
\hline \multirow[t]{6}{*}{ Halal Lifestyle } & Item 1 & 0,395 & \multirow[t]{6}{*}{0,3061} & Valid \\
\hline & Item 2 & 0,536 & & Valid \\
\hline & Item 3 & 0,443 & & Valid \\
\hline & Item 4 & 0,653 & & Valid \\
\hline & Item 5 & 0,684 & & Valid \\
\hline & Item 6 & 0.678 & & Valid \\
\hline \multirow{8}{*}{$\begin{array}{c}\text { Halal } \\
\text { Awareness }\end{array}$} & Item 1 & 0,704 & \multirow[t]{8}{*}{0,3061} & Valid \\
\hline & Item 2 & 0,743 & & Valid \\
\hline & Item 3 & 0,624 & & Valid \\
\hline & Item 4 & 0,663 & & Valid \\
\hline & Item 5 & 0,735 & & Valid \\
\hline & Item 6 & 0,671 & & Valid \\
\hline & Item 7 & 0,761 & & Valid \\
\hline & Item 8 & 0,726 & & Valid \\
\hline \multirow[t]{6}{*}{ Price } & Item 1 & 0,823 & \multirow[t]{6}{*}{0,3061} & Valid \\
\hline & Item 2 & 0,333 & & Valid \\
\hline & Item 3 & 0,840 & & Valid \\
\hline & Item 4 & 0.807 & & Valid \\
\hline & Item 5 & 0.840 & & Valid \\
\hline & Item 6 & 0.756 & & Valid \\
\hline \multirow{8}{*}{$\begin{array}{l}\text { Repurchase } \\
\text { Intention }\end{array}$} & Item 1 & 0,567 & \multirow[t]{8}{*}{0,3061} & Valid \\
\hline & Item 2 & 0,620 & & Valid \\
\hline & Item 3 & 0,719 & & Valid \\
\hline & Item 4 & 0,628 & & Valid \\
\hline & Item 5 & 0,848 & & Valid \\
\hline & Item 6 & 0,834 & & Valid \\
\hline & Item 7 & 0,842 & & Valid \\
\hline & Item 8 & 0,727 & & Valid \\
\hline \multirow{6}{*}{$\begin{array}{l}\text { Consumer } \\
\text { Satisfaction }\end{array}$} & Item 1 & 0,749 & \multirow[t]{6}{*}{0,3061} & Valid \\
\hline & Item 2 & 0,822 & & Valid \\
\hline & Item 3 & 0,819 & & Valid \\
\hline & Item 4 & 0,672 & & Valid \\
\hline & Item 5 & 0,853 & & Valid \\
\hline & Item 6 & 0,696 & & Valid \\
\hline
\end{tabular}

Source: Processed primary data, 2021

Based on the table above, it is known that all question items in the questionnaire are valid, it can be seen in each question item where all the results of $r$ count $>r$ table $(0.3061)$ 


\section{$A I C \overline{I E B} \quad$ Annual International Conference \\ on Islamic Economics and Business, 2021}

\subsection{Reliability Test}

Table 2. Reliability Test Results

\begin{tabular}{|c|c|c|}
\hline Variable & Cronbach's Alpha & Description \\
\hline Halal Lifestyle & 0,707 & Reliabel \\
\hline Halal Awareness & 0,844 & Reliabel \\
\hline Price & 0,837 & Reliabel \\
\hline Repurchase Interest & 0,870 & Reliabel \\
\hline Customer Satisfaction & 0,860 & Reliabel \\
\hline
\end{tabular}

Source: Processed primary data, 2021

Based on the table above, it can be seen that the results of the reliability test show that the overall value of Cornbach's Alpha of each variable is $>0.60$, which means it is reliable and can be used for further research.

\subsection{T Test}

Table 3. T Test Results Equation 1

\begin{tabular}{|c|c|c|c|c|}
\hline No & Variable & $\begin{array}{c}\text { Unstandardized } \\
\text { Coefficients (B) }\end{array}$ & T Count & Significance \\
\hline 1 & Konstanta & 1,829 & 0,685 & 0,495 \\
\hline 2 & Halal Lifestyle & $-0,008$ & $-0,084$ & 0,933 \\
\hline 3 & $\begin{array}{c}\text { Halal } \\
\text { Awareness }\end{array}$ & 0,435 & 6,607 & 0,000 \\
\hline 4 & Price & 0,364 & 4,319 & 0,000 \\
\hline
\end{tabular}

Source: Processed primary data, 2021

Based on the table above, it can be concluded that the regression equation model is as follows:

$$
Y=1,829-0,008 X 1+0,435 X 2+0,364 X 3+e 1
$$

Based on the results of the $T$ test (partial) in the table above, it can be concluded that:

1. The significance value of the halal lifestyle variable (X1) is $0.933>0.05$. This shows that the halal lifestyle variable (X1) has no effect on consumer satisfaction (Z).

2. The significance value of the halal awareness variable (X2) is $0.000<0.05$. This shows that the halal awareness variable (X2) has a positive and significant influence on the consumer satisfaction variable.

3. The significance value of the price variable (X3) is $0.000<0.05$. This shows that the price variable (X3) has a positive and significant effect on the variable of consumer satisfaction.

Table 4. T Test Results Equation II

\begin{tabular}{|c|c|c|c|c|}
\hline No & Variable & $\begin{array}{c}\text { Unstandardized } \\
\text { Coefficients (B) }\end{array}$ & T Count & Significance \\
\hline 1 & Halal Lifestyle & $-7,368$ & $-1,452$ & 0,150 \\
\hline 2 & $\begin{array}{c}\text { Halal } \\
\text { Awareness }\end{array}$ & 0,372 & 1,972 & 0,052 \\
\hline 3 & Price & $-0,126$ & $-0,837$ & 0,404 \\
\hline 4 & $\begin{array}{c}\text { Repurchase } \\
\text { Interest }\end{array}$ & 0,622 & 3,563 & 0,001 \\
\hline 5 & $\begin{array}{c}\text { Customer } \\
\text { Satisfaction }\end{array}$ & 0,653 & 3,379 & 0,001 \\
\hline
\end{tabular}

Source: Processed primary data, 2021

Based on the table above, it can be concluded that the regression equation model is as follows: 


\section{$A I C \overline{I E B}$ Annual International Conference \\ on Islamic Economics and Business, 2021}

$$
Y=-7,368+0,372 X 1-0,126 X 2+0,622 X 3+0,653 Z+e 1
$$

Based on the results of the T test (partial) in the table above, it can be concluded that:

1. The significance value of the halal lifestyle variable (X1) is $0.052>0.05$. This shows that the halal lifestyle variable (X1) has a positive and insignificant effect on repurchase interest (Y).

2. The significance value of the halal awareness variable (X2) is $0.404>0.05$. This shows that the halal awareness variable (X2) has no effect on the repurchase intention variable (Y).

3. The significance value of the price variable $(\mathrm{X} 3)$ is $0.01<0.05$. This shows that the price variable (X3) has a positive and significant effect on the repurchase interest variable (Y).

4. The significance value of the consumer satisfaction variable $(Z)$ is $0.001<0.05$. This shows that the variable of consumer satisfaction $(Z)$ has a positive and significant effect on the variable of repurchase interest $(\mathrm{Y})$.

\subsection{F Test}

Table 5. F Test Result

\begin{tabular}{|c|c|c|}
\hline Model & F Count & Significance \\
\hline Regression & 23.408 & $0,000 \mathrm{~b}$ \\
\hline
\end{tabular}

Source: Processed primary data, 2021

Based on the table above, it shows that the significance value is $0.000<0.05$. It can be concluded that the variables of halal lifestyle, halal awareness, price and consumer satisfaction simultaneously (simultaneously) affect repurchase interest.

\subsection{R2 Test}

Table 6. R2 Test Results (Equation 1)

\begin{tabular}{|c|c|c|}
\hline Model & $\mathrm{R}$ & $\begin{array}{c}\text { Adjusted R } \\
\text { Square }\end{array}$ \\
\hline 1 & 0,794 & 0,619 \\
\hline
\end{tabular}

Source: Processed primary data, 2021

Based on the table above, the correlation coefficient $\mathrm{R}$ is 0.794 , which means that the independent variable has a strong relationship with the dependent variable. While the results of the R2 test in this study obtained an R2 value of 0.619 . This shows that $61.9 \%$ of consumer satisfaction variables are influenced by variables of halal lifestyle, halal awareness, price and the remaining $38.1 \%$ is influenced by other variables.

Table 7. R2 Test Results (Equation 2)

\begin{tabular}{|c|c|c|}
\hline Model & $\mathrm{R}$ & $\begin{array}{c}\text { Adjusted R } \\
\text { Square }\end{array}$ \\
\hline 1 & 0,705 & 0,475 \\
\hline
\end{tabular}

Source: Processed primary data, 2021

Based on the table above, the correlation coefficient $\mathrm{R}$ is 0.705 , which means that the independent variable has a strong relationship with the dependent variable. While the results of the R2 test in this study obtained an R2 value of 0.475 . This shows that $47.5 \%$ of the 


\section{$A \mathrm{C} \overline{I E B}$ Annual International Conference \\ on Islamic Economics and Business, 2021}

variables of repurchase interest are influenced by the variables of halal lifestyle, halal awareness, prices and the remaining $52.5 \%$ is influenced by other variables.

\subsection{Sobel Test Results}

3.6.1 Effect of halal lifestyle $(\mathrm{X} 1)$ on repurchase interest $(\mathrm{Y})$ through consumer satisfaction $(Z)$

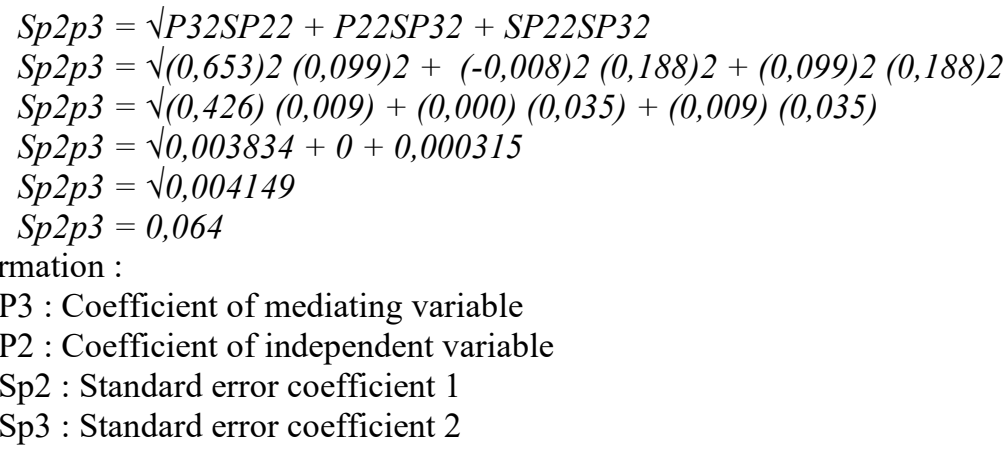

Based on the direct effect of halal lifestyle with repurchase intention of -0.008 , while the indirect effect $(\mathrm{P} 1 \mathrm{X} \mathrm{P} 7)=(-0.008 \times 0.653)=-0.005224$ with a total effect of P4 $+(\mathrm{P} 1 \mathrm{X}$ $\mathrm{P} 7)=0.372+(-0.005224)=0.366776$.

Based on sp2sp3 can be calculated the statistical $t$ value of the mediation effect with the formula:

$$
\begin{aligned}
t & =p 2 p 3: S p 2 p 3 \\
& =-0,005224: 0,064 \\
& =-0,081625
\end{aligned}
$$

Therefore, the value of $\mathrm{t}$ count $=-0.081625<\mathrm{t}$ table $=1.66055$. There is no mediation effect.

3.6.2 Effect of halal awareness (X2) on repurchase interest $(\mathrm{Y})$ through consumer satisfaction $(Z)$

$$
\begin{aligned}
& S p 2 p 3=\sqrt{ } P 32 S P 22+P 22 S P 32+S P 22 S P 32 \\
& S p 2 p 3=\sqrt{ }(0,653) 2(0,066) 2+(0,435) 2(0,150) 2+(0,066) 2(0,150) 2 \\
& S p 2 p 3=\sqrt{ }(0,426)(0,004)+(0,189)(0,022)+(0,004)(0,022) \\
& S p 2 p 3=\sqrt{0,001704+0,004158+0,000088} \\
& S p 2 p 3=\sqrt{ } 0,00595 \\
& S p 2 p 3=0,077
\end{aligned}
$$

Information :

P3 : Coefficient of mediating variable

P2 : Coefficient of independent variable

Sp2 : Standard error coefficient 1

Sp3 : Standard error coefficient 2

Based on the direct effect of halal awareness with repurchase intention of 0.435 , while the indirect effect $(\mathrm{P} 2 \mathrm{X} \mathrm{P} 7)=(0.435 \times 0.653)=0.284055$ with a total effect of P5 $+(\mathrm{P} 2 \mathrm{X}$ P7 $)$ $=-0.126+0.284055=0,158055$. 


\section{$A \mathrm{I} \overline{I E B}$ Annual International Conference \\ on Islamic Economics and Business, 2021}

Based on sp2sp3 can be calculated the statistical $t$ value of the mediation effect with the formula:

$$
\begin{aligned}
t & =p 2 p 3: S p 2 p 3 \\
& =0,284055: 0,077 \\
& =3,6890
\end{aligned}
$$

Therefore, the value of $\mathrm{t}$ count $=3.6890>\mathrm{t}$ table $=1.66055$. There is mediation effect.

\subsubsection{Effect of price $(\mathrm{X} 3)$ on repurchase interest $(\mathrm{Y})$ through consumer satisfaction} (Z)

$$
\begin{aligned}
& S p 2 p 3=\sqrt{ } P 32 S P 22+P 22 S P 32+S P 22 S P 32 \\
& S p 2 p 3=\sqrt{ }(0,653) 2(0,084) 2+(0,364) 2(0,175) 2+(0,084) 2(0,175) 2 \\
& S p 2 p 3=\sqrt{ }(0,426)(0,007)+(0,132)(0,030)+(0,007)(0,030) \\
& S p 2 p 3=\sqrt{ } 0,002982+0,00396+0,00021 \\
& S p 2 p 3=\sqrt{ } 0,00417 \\
& S p 2 p 3=0,064
\end{aligned}
$$

Information :

P3 : Coefficient of mediating variable

P2 : Coefficient of independent variable

Sp2 : Standard error coefficient 1

Sp3 : Standard error coefficient 2

Based on the direct effect of price with repurchase intention of 0.364 , while the indirect effect $(\mathrm{P} 3 \mathrm{X}$ P7 $)=(0.364 \times 0.653)=0.237692$ with a total effect of P6 $+(\mathrm{P} 3 \mathrm{X}$ P7 $)=0.622+$ $0.237692=0.897692$.

Based on sp2sp3 can be calculated the statistical $t$ value of the mediation effect with the formula:

$$
\begin{aligned}
t & =p 2 p 3: S p 2 p 3 \\
& =0,237692: 0,064 \\
& =3,7139
\end{aligned}
$$

Therefore, the value of $\mathrm{t}$ count $=3.7139>\mathrm{t}$ table $=1.66055$. There is mediation effect.

\subsection{Discussion}

Based on the results of the study, it is known that the halal lifestyle variable has a positive and insignificant effect on repurchase interest at the Kedu Susu shop. This is in line with research conducted by Riptiono (2013). These results indicate that lifestyle does not have a significant effect on repurchase intention. This study shows that in line with research conducted by researchers that there is no influence between halal lifestyle on repurchase interest at the Kedu Susu shop in Temanggung because consumers who come to the Kedu Susu shop are not too concerned with the Islamic lifestyle.

Furthermore, the halal awareness variable has no effect on repurchase interest at the Kedu Susu shop. This is in line with research conducted by Prastiwi \& Auliya (2016), with research results showing that halal awareness does not have a significant effect on repurchase intention. This shows that there is no relationship between halal awareness and repurchase intention at the Kedu Susu shop in Temanggung.

The effect of price on repurchase interest, shows that the price variable has a positive and significant effect on repurchase interest at the Kedu Susu shop, so H3 is accepted. This is in line with research conducted by Rosita (2016), the price variable has a positive and significant effect on consumer repurchase interest. This shows that the higher the price 


\section{$A I \overline{C E B}$ Annual International Conference \\ on Islamic Economics and Business, 2021}

offered, the higher the level of product quality which will lead to higher repurchase interest at the Kedu Susu shop in Temanggung.

The relationship between Halal Lifestyle and Consumer Satisfaction, shows that the Halal Lifestyle variable has no influence on consumer satisfaction when visiting the Kedu Susu shop. This is in line with research conducted by Wijanarko (2016) with results showing that intervariables do not have a significant effect. In this study, it is stated that there is no relationship between Halal lifestyle and consumer satisfaction, which means that the higher a person's Islamic lifestyle does not lead to the more satisfied someone in buying products at the Kedu Susu Temanggung shop.

Furthermore, the halal awareness variable has a positive and significant effect on consumer satisfaction visiting the Kedu Susu shop. This is in line with research conducted by Ryan (2018), whose research results show that the halal awareness variable has a significant influence on product satisfaction. This shows that halal awareness affects the level of consumer satisfaction where the higher a person's faith, the more aware a person is of the quality and facilities at the Kedu Susu shop, so that with adequate facilities and quality, especially in terms of supporting worship, the more satisfied someone visits. kedu milk shop in Temanggung.

The effect of price on consumer satisfaction shows a positive and significant effect. This is in line with research conducted by Islami (2019) with the results showing that service quality, servicescape, and price partially have a positive and significant influence on customer satisfaction. This shows that the higher the price level given with supporting quality, the higher the level of consumer satisfaction to visit the Kedu Susu shop in Temanggung.

The variable of consumer satisfaction has a positive and significant effect on repurchase interest at the Kedu Susu shop. This is in line with research conducted by Ma'mun et al. (2014) with results showing the influence of customer satisfaction on repurchase interest. Thus the results of this study indicate that the better the quality and facilities provided by the Kedususu shop will further increase customer satisfaction which will directly increase the interest in repurchasing at the Kedu Susu shop in Temanggung.

The results of further research indicate that the consumer satisfaction variable cannot mediate the effect of halal lifestyle on repurchase intention. This is in line with research conducted by Milo (2019) showing that customer satisfaction does not mediate when it becomes an intervening variable on the variable of repurchase interest. Then the halal lifestyle variable has no effect on repurchase interest through consumer satisfaction. This means that consumers are not concerned with aspects of customer satisfaction, but the suitability of other factors in this study. Because the higher a person's Islamic lifestyle will not increase interest in revisiting the Kedu Susu shop so it will not increase consumer satisfaction at the Kedu Susu shop in Temanggung.

The variable of consumer satisfaction is able to mediate the effect of halal awareness on repurchase intention. This is in line with the research conducted by resulted in customer satisfaction variables significantly mediating the effect of experience on repurchase intentions, this means that repurchase intentions will increase if experience can increase customer satisfaction, increasing halal awareness will increase purchase satisfaction which will then intend to repurchase at the Kedu Susu shop in Temanggung.

Furthermore, consumer satisfaction is able to mediate the effect of price on repurchase intention. This is in line with research conducted by Setiawan \& Safitri (2019), with the results showing that the price variable has a positive and significant effect and the consumer satisfaction variable has a positive and significant effect on repurchase interest, thus it can be concluded that price has a positive and significant effect on repurchase intention with satisfaction as an intervening variable. The better the price offered, the more repeat purchases and will lead to consumer satisfaction on every purchase at the Kedu Susu shop. 


\section{$A \mathrm{IC} \quad$ Annual International Conference \\ on Islamic Economics and Business, 2021}

\section{Conclusion}

Based on the results of this study using instrument tests, statistical tests, classical assumption tests and also the Sobel test resulted that the halal lifestyle variable had no significant positive effect, halal awareness had no effect while price had a significant positive effect on repurchase interest. Consumer satisfaction has a significant positive effect on repurchase intention. Consumer satisfaction is not able to mediate the effect of halal lifestyle on repurchase intention, while consumer satisfaction is able to mediate the effect of halal awareness and price on repurchase interest.

\section{References}

Ajzen, I. (1991). The theory of planned behavior. Organizational Behavior and Human Decision Processes, 50(2), 179-211. https://doi.org/10.1016/0749-5978(91)90020-T

Ajzen, I. (2012). The theory of planned behavior. Handbook of Theories of Social Psychology: Volume 1, January 2012, 438-459. https://doi.org/10.4135/9781446249215.n22

Aldeen, K. N., Ratih, I. S., \& Pertiwi, R. S. (2021). Cash waqf from the millennials' perspective: a case of Indonesia. ISRA International Journal of Islamic Finance.

Annisa, A. A. (2021). Islamic Financial Literacy Cycle in the Family. Indonesian Journal of Islamic Economics Research, 3(1).

Arinda, M. K. (2020). Pengaruh Halal Lifestyle, Harga, Dan Promosi Terhadapkeputusan Konsumenmemilih Kayla Nissasalon \& Spamuslimah. In Journal of Chemical Information and Modeling.

C.S.S., M. V. (2018). Pengaruh Kepuasan Dan Kepercayan Terhadap Minat Beli Ulang Konsumen. In Universitas Santa Dharma Yogyakarta (Vol. 151, Issue 2).

Dewi, W. S., Hasiolan, L. B., \& Minarsih, M. M. (2016). Pengaruh Kualitas Produk, Kepercayaan Terhadap Keputusan Pembelian Dengan Kepuasan Konsumen Sebagai Variabel Intervening. Journal of Management, 2(2).

Imah, B. (2020). Pengaruh Kesadaran Halal Dan Label Halal Terhadap Keputusan Pembelian Produk Kosmetik.

Islami, V. (2019). Pengaruh Kualitas Pelayanan, servicescape Dan Harga Terhadap Kepuasan Konsumen. Jurnal Sekretaris Dan Manajemen, 3(2). https://doi.org/10.37366/ekomabis.v1i01.2

Ismailia, Y. (2018). Pengaruh gaya hidup syariah dan harga terhadap keputusan pembelian pada klinik kecantikan muslimah aishaderm. Ekonomi Dan Bisnis Islam, 107.

Khan, S., Haleem, A., \& Khan, M. I. (2020). Risk management in Halal supply chain: an integrated fuzzy Delphi and DEMATEL approach. Journal of Modelling in Management, 16(1), 172-214. https://doi.org/10.1108/JM2-09-2019-0228

Kotler, \& Keller. (2009). Manajemen Pemasaran (12th ed.). Erlangga.

Kotler, P., \& Amstrong, G. (2012). Prinsip-Prinsip Pemasaran (13th ed). Erlangga.

Ma'mun, M., Widiyanto, I., \& Mudiantono. (2014). Study Tentang Kepuasan Pelanggan Dan Minat Membeli Ulang. Jurnal Sains Pemasaran Indonesia, 13(3), 259-277. https://doi.org/10.14710/jspi.v13i3.259-277

Milo, marselina rosarin. (2019). Pengaruh Kualitas Makanan dan Kualitas Pelayanan terhadap Kepuasan Pelanggan serta Implikasinya terhadap Minat Pembelian Ulang Taman Kuliner KUMKUM. Jurnal Ilmiah Manajemen Dan Bisnis, 5, 1-11.

Nelwan, O., \& Mandey, S. (2014). Customer Relationship Management (Crm) Dan Personal Selling Pengaruhnya Terhadap Kepuasan Konsumen Pada Pt Virgo Ekspres Tours \& Travel Manado. Jurnal Riset Ekonomi, Manajemen, Bisnis Dan Akuntansi, 2(1), 99110. https://doi.org/10.35794/emba.v2i1.3559 


\section{$A \overline{I E B}$ Annual International Conference \\ on Islamic Economics and Business, 2021}

Nikmatul, R. (2020). In Pengaruh Kesadaran Halal, Islamic Branding Dan Product Ingredients Terhadap Minat Beli Luwak White Coffiepada Masyarakat Desa Danau Kecamatan Pelepat Ilir Kabupaten Bungo (Vol. 8, Issue 5). UIN Jambi.

Prastiwi, S. K. dan, \& Auliya, Z. F. (2016). Apakah Halal Awareness dapat meningkatkan Repurchase Intention? Do Halal Awareness Increasing Repurchase Intention? Ebbank, $7(2), 55-64$.

Riptiono, S. (2013). Pengaruh Lifestyle, Brand Awareness dan Product Quality terhadap Repurchase Intention Minuman Saribuah Buavita dengan Purchasing Decisions sebagai Variabel Intervening di Kecamatan Kebumen. Fokus Bisnis, 12(1), 99-117.

Rosita, R. (2016). Pengaruh Lokasi, Kelengkapan Produk, Kualitas Produk, Pelayanan, Harga, Dan Kenyamanan Berbelanja terhadap Minat Beli Ulang Konsumen Pada Lotte Mart Bekasi Junction. Jurnal Ilmiah WIDYA Ekonomika, 1(2), 98-103.

Ryan, R. (2018). Analisis Halal supply Chain Management Produk Kosmetik Halal Terhadap Tingkat Kesadaran dan Kepuasan Mahasiswi Yogyakarta. In Universitas Islam Indonesia. UII.

Sartika, D. (2017). Analisis Faktor-Faktor Yang Mempengaruhi Minat Beli Ulang Produk You C 1000 Serta Dampaknya Terhadap Loyalitas Konsumen. Jurnal Penelitan Ekonomi Dan Bisnis, 2(1), 10-21. https://doi.org/10.33633/jpeb.v2i1.2231

Satu, B. (2016). Mengulik Tren Global Bisnis Halal di IIHLEC 2016.

Setiawan, W., \& Safitri, K. (2019). Pengaruh Kualitas Produk dan Harga Terhadap Minat Beli Ulang Beras Batang Gadis Di Agen S. Riyadi Melalui Kepuasan Konsumen Sebagai Variabel Intervening. Jurnal Ilmu MEA, 3(3). https://doi.org/10.31955/mea.vol3.iss3.pp223-231

Shantika, ketut adi ananta, \& Setiawan, putu yudi. (2019). peran kepuasan pelanggan dalam memediasi persepsi nilai dan pengalaman terhadap niat membeli ulang kembali. $E$ Jurnal Manajemen, Vol. 8 No. 6, 8(6), 3902-3929.

Sudarti, K., \& Ulum, S. B. (2019). Peran Sikap Konsumen Dalam Memediasi Pengaruh Religiusitas Dan Reputasi Merek Terhadap Minat Beli Ulang. Jurnal Ekonomi Dan Bisnis, 20(2), 48. https://doi.org/10.30659/ekobis.20.2.48-61

Widyatami, K., Hurriyati, R., \& Wibowo, L. A. (2019). Model Perilaku Pengendara Sepeda Di Kota Bandung Berdasarkan Theory of Planned Behavior Bicycle Commuting Behavior Model in Bandung Based on Theory of Planned Behavior. 18(2), 54-62.

Wijanarko, P. (2016). Pengaruh kualitas pelayanan dan religiusitas terhadap kepuasan nasabah serta dampaknya pada loyalitas nasabah. Universitas Islam Negeri Syarif Hodayatullah Jakarta.

Yesi, A. E. dkk. (2016). Pengaruh Kualitas Pelayanan, Fasilitas Dan Variasi produk (Restoran) terhadap Minat Beli Ulang Pelanggan. Journal of Chemical Information and Modeling, 53(9). 